\title{
MIĘDZY LĘKIEM A FASCYNACJA. POJĘCIE POWIETRZA W DZIEJACH POLSZCZYZNY
}

Tematyka żywiołów od pewnego czasu budzi zainteresowanie wśród naukowców różnych dziedzin, o czym świadczą i organizowane konferencje, i wydawane publikacje. Sporo uwagi poświęcono też samemu powietrzu, choć zwykle opisuje się je w kontekście kulturowym, nie sposób nie wspomnieć też o pracach językoznawczych (głównie $z$ ośrodka lubelskiego) poruszających tę problematykę. ${ }^{1}$

To zainteresowanie oczywiście nie dziwi. Czymś naturalnym jest przyglądanie się

żywiołom jako realnym siłom przyrody, które w jakimś sensie kształtują nas i otaczające nas środowisko, żywiołom kreującym i rozbudzającym wyobraźnie literacką i plastyczną, w których centrum zawsze znajduje się człowiek [Wilk 2007, 9].

Niniejsze rozważania, w których proponuję ogląd historyczny, wynikają właśnie $z$ takiej naturalnej potrzeby poznania i zrozumienia nie tyle samej istoty wymienionego w tytule żywiołu, ile raczej naszych wyobrażeń o nim, zmienności i samego pojęcia, i jednocześnie stosunku człowieka do zjawisk przyrodniczych. Interesować mnie będa zatem przyjęte w społeczności sądy, a nie myśl naukowa, choć oba punkty widzenia się zazębiają. Historyczny opis językoznawczy jest tu potrzebny choćby $z$ tego względu, iż powszechne było i jest odwoływanie się do omawianego pojęcia i w metaforze, i w porównaniach.

Pewna komplikacją w analizach pojęcia <powietrze> wprowadza jego wieloaspektowość. $Z$ jednej strony mamy do czynienia $z$ percepcja związana $z$ prostym, bezpośrednim doświadczeniem, $z$ drugiej, $z$ kulturowym obrazem, ukształtowanym $z$ nakładajacych się na siebie różnych tradycji: chrześcijańskiej i słowiańskiej, wielowiekowej myśli filozoficz-

1 Chodzi przede wszystkim o prace: Niebrzegowska-Bartmińska, Bartmiński 2017 oraz hasła w SSiSL Powietrze, Powietrze morowe [oprac. G. Baczkowska, J. Szadura], Wiatr [oprac. J. Bartmiński, G. Baczkowska, K. Prorok], Wir powietrzny [oprac. J. Bartmiński, G. Bączkowska]. 
nej, naukowej. W ciagu wieków to postrzeganie podlegało, choć trudno uchwytnym, ale dość istotnym zmianom. Tak jak jednak stosunkowo łatwo prześledzić koncepcje naukowe na temat powietrza i innych żywiołów, tak znacznie bardziej skomplikowane jest dotarcie do wyobrażeń przeciętnego dawnego człowieka. Ma pewną rację Natalia Gryzińska, piszac o wiekach średnich i odwołując się do teorii Arona Guriewicza, że „...w jaki sposób zwyczajni ludzie postrzegali żywioły, możemy tylko domniemywać na podstawie kierowanych do nich przekazów" [Gryzińska $2011,45] .{ }^{2}$ Językoznawca doda jednak jeszcze inne narzędzia badawcze, które pozwalaja odczytać ukryte treści w tekście i języku. Odczytania te daja co prawda obraz dość mglisty, ale jednak w pewien sposób dokumentują dawną mentalność.

Ponieważ podstawowym leksemem związanym $z$ pojęciem <powietrze> jest przez wszystkie wieki w polszczyźnie właśnie powietrze, ${ }^{3}$ to słowo stanowić będzie podstawę dalszych rozważań. W analizach, $z$ konieczności uproszczonych, wykorzystuję materiał zebrany w dużej mierze ze słowników historycznych i dawnych, w przekonaniu, iż stanowia razem $z$ korpusami najbogatszą $z$ możliwych dokumentację, ale również sięgam po inne teksty źródłowe.

1. Nawet pobieżny przegląd definicji zawartych w słownikach historycznych pozwala uchwycić pierwsze zasadnicze różnice względem współczesności: przede wszystkim większa pojemność semantyczną analizowanego wyrazu. Tę wieloznaczność rejestruja już teksty staropolskie, w późniejszych wiekach jest ona jednak jeszcze wyraźniejsza. Przykładowo, według autorów SXVI powietrze oznacza $z$ jednej strony 'przestrzeń między ziemia a niebem', a także samo 'niebo, firmament', 'niewidzialne ciało lotne, wiatr', 'zarazę, epidemię', 'stan pogody, klimat'. ${ }^{4}$

Co ciekawe, podobna polisemię odnajdziemy również w innych językach, por. np. w staro- i średnio-wysoko-niemieckim:

Luft f: 'die Erde umgebendes Gasgemenge, Atmosphäre, leichter Wind, freier Raum, Zwischenraum', mhd. asächs. luft m. f. 'Luft, Wind, Himmel [DWDS, zob. też Pawlikowska-Asendrych 2012]

2 N. Gryzińska przypomina pracę Arona Guriewicza [1987]. Ten znany badacz średniowiecza wychodził $z$ założenia, że aby poznać świadomość niższych warstw społecznych w średniowieczu, należałoby uważniej studiować przekazy do nich skierowane przez elity. Przekazy te bowiem, jeśli miały dotrzeć do prostych ludzi, musiały zawierać elementy ich postrzegania świata. Jak pisze A. Guriewicz: „Ażeby poglądy społecznej i duchowej elity stały się poglądami panujacymi, należało je przełożyć na język zrozumiały dla wszystkich" [Guriewicz1987, 16].

3 Istniejace jeszcze określenia wzduch / wozduch maja charakter marginalny.

4 Podaję definicje słownikowe w uproszczeniu. 
czy w staroczeskim

povětriie: vzduch (jako živel a zvl. podmínka dýchání); povětří, ovzduší, vzdušný prostor mezi nebem a zemí; vítr, proudění vzduchu; vichřice, ničivě silný vítr, povětří (arch.); povětrnost, počasí, stav ovzduší; podnebí, povětrnostní podmínky [SS].

A zatem polski leksem odzwierciedla w swej semantyce w dużej mierze ogólny sposób myślenia, charakterystyczny nie tylko dla kultury polskiej, ale mocno tkwiacy w europejskich schematach wyobrażeniowych.

Dwa podstawowe sensy powietrza zwiazane $z$ jednej strony $z$ miejscem, $z$ drugiej z sama materią wymagają odrębnych rozważań.

2. Powietrze jako miejsce

2.1. Stanisława Niebrzegowska-Bartmińska i Jerzy Bartmiński, przywołując etymologię interesującego nas leksemu, utworzonego podobnie jak derywaty typu polesie, pobocze, zwracaja uwagę, że wyraz ów ma „wpisany w swoja sematykę sem przestrzeni” [Bartmiński, Niebrzegowska-Bartmińska 2017, 22]. We współczesnej polszczyźnie przypominają o tym zwiąki typu wzbić sie $w$ powietrze, zawisł $w$ powietrzu czy wyjść na świeże powietrze, być na (otwartym, wolnym) powietrzu. Wartość ta była jednak, jak sądzę, mocniej eksponowana w dawnej polszczyźnie, o czym przekonują nas choćby zdania typu:

(...) wieśniak ieden na iego grobie skrzynię z zbożem położył / niebacżąc iaki tam człowiek leżał. Tedy wicher $z$ powietrza / innych rzeczy zaniechawszy/ skrzynię onę samę wyniosł y daleko zarzućił SkarŻyw 213. 3 [SXVI].

Warto byłoby jednak przede wszystkim zastanowić się nad tym, o jakim miejscu mówimy w wypadku powietrza. Zwróćmy uwagę, że leksemem tym oznaczano nie tylko to, co dziś określamy jako 'przestrzeń między ziemia a niebem, atmosferę', ale też 'niebo, firmament'. Moglibyśmy w pewnym uproszczeniu przyjąć, że analizowane słowo wskazywało cała przestrzeń powyżej ziemi. Zwróćmy uwagę np. na fragment dzieła Jana Kochanowskiego:

Nie wiem, czego więcej trzeba, Przećiwko nim świadczą n i e b i o s a: Świadczą gwiazdy niezliczone / Na powietrzu zapalone KochFrag 18. 122 [SXVI].

Meandry znaczeniowe powietrza pośrednio tłumaczy ks. Jakub Wujek przy okazji rozważań terminologicznych w jednym $z$ komentarzy do Ksiegi Genesis:

Co tu łaciński tłumacz firmamentum (...), to iest utwierdzenim abo twierdza zowie / to inni z żydowskiego (...) rakiah, expansio, rościag / rościagnienie abo powietrze przekładają. Przez co się rozumie wszytko to / spatium, i ten wszytek przeciag ktory jest nad nami / od ziemie aż do nieba / który w sobie ma powietrze y niebo [Wujek 1599, Księga Genesis, Przekłady miejsc trudniejszych]. 
Przytoczony fragment jest o tyle ciekawy, że autor podaje w nim kilka bliskoznaczników, takich jak: rozciag, rozciagnienie, przeciag. Dodać do tego można byłoby jeszcze szesnastowieczne przestworze, rozpostrzeżenie itd. Wszystko to świadczy o coraz większej potrzebie nazewniczej. Głównie jednak, podkreślmy, ów problem dotyczył rozważań naukowych.

Historia leksyki polskiej oddaje zmienność oglądu tej sfery świata, zmienność myśli naukowej, ale też przeobrażenia mentalne przeciętnego człowieka. Wraz z odchodzeniem pewnych dawnych wyobrażeń znikają niektóre określenia, np. mierne, wysokie, niebieskie powietrze, które wskazywały różne sfery między niebem a ziemią. Powstają też nowe słowa. W XVIII wieku np. po raz pierwszy użyto obcego leksemu atmosfera, który dokumentuje kształtowanie się nowego, odrębnego pojęcia. $Z$ czasem pojawiaja się w polszczyźnie, choć na krótko (XVIII, XIX wiek) dwa derywaty na określenia przestrzeni między niebem a ziemią: powietrzokrag, określony w słowniku Lindego jako "powietrze na około ziemi rozlane' [SL] i powietrznia o podobnej semantyce. Warto zwrócić uwagę, że nie zawsze używane były w znaczeniu ściśle terminologicznym, por.:

Po zachodzie słońca powietrzokrag jeszcze jego promienie ku nam przesyła i daje światło zmierzchem czyli mrokiem wieczornym nazywane Ztąd elegijny charakter budzi żal za ustępująca jasnością dnia a trwogę [Libert 1875, 151].

2.2. Naturalne skojarzenie powietrza $z$ przestworem musi wiazać się oczywiście $z$ pewnymi pozytywnymi konotacjami, $z$ wolnościa, przestrzennościa (por. np. derywat powietrznie: Wszędzie przestronno i powietrznie Sienk, Listy III, 154 [SDor]). Jednocześnie jednak przestrzeń ta, charakteryzująca się też specyficzna substancjonalnością, była przez wieki niemożliwa do penetracji przez człowieka, co z pewnością wpływało na jej ogląd, wywoływało lęk przed nieznanym i tak eterycznym. W dawnych wiekach to drugie spostrzeganie zdecydowanie dominowało. Zachowały się do naszych czasów liczne ślady pojmowania powietrza-miejsca jako szczególnego pola działania sił nadprzyrodzonych. $Z$ jednej strony przez zwiazek $z$ sensem 'niebo', por.:

By sza pothnoszyl na povyetrze, mvszysz placzycz swyanthopyetrze De morte w. 394 [Sstp].

Ano też i Paweł s. powieda / iż był wzięt aż do trzeciego nieba. Ale obacz czyją się to moca działo. Zadny moca swą nie wstapił na powietrze Rej Ps 135v [SXVI],

$z$ drugiej ze względu na przekonanie, iż jest to siedlisko diabłów i wszelkich złych mocy, miejsce ich działania. Dzieła sztuki tamtych czasów, teksty językowe ten świat wyobraźni pokazuja bezpośrednio, a jest to świat nie tylko polski. Oto jeden $z$ wielu przykładów: historia Szymona Czarnoksiężnika. W Monachium zamieszczono na ołtarzu św. Piotra 
i Pawła scenę unoszenia maga przez diabły. To XV wiek [JankiewiczBrzostkowska 2007, 312]. I jednocześnie tę sama opowieść odnajdziemy na kartach Żywotów świętych Piotra Skargi z charakterystycznym, istotnym dla nas, fragmentem:

y zpuśćiwszy się z góry / pocżą ná powietrzu latać (bo go cżárći nieśli) ludzie się zdumiewáli bárzo / SkarŻyw 601 [korpus SXVI].

Powyższy przykład stanowi jedną $z$ bardzo wielu ilustracji wspólnych europejskich korzeni kulturowych.

Polskie wyobrażenia powietrza nasączone sa jednak też słowiańskimi wierzeniami. Mamy do czynienia $z$ ciekawym związkiem dwóch różnych tradycji kulturowych. Warto przypomnieć nazwy całego szeregu złych duchów powietrznych, traktowanych często jako rodzaj diabłów, które zostały zarejestrowane w dawnych tekstach: latawiec, latawica, pochwist, pogwizd, południca, obłocznik itd. [Krótki 2016]..$^{5}$ O powszechności wiary $\mathrm{w}$ ich istnienie $\mathrm{w}$ XVI wieku świadczą wcale nie tak rzadkie odwołania w literaturze, np. u Mikołaja Reja:

owi dyabełkowie co ie latáwcámi zowiemy ktorzy tu proste ludzi á o Bogu máło wiedzące obłudnościámi swemi á chytrościámi swemi $z$ wiáry zwodzą RejAp 148 [SXVI].

Do dziś w gwarach zachowało się jeszcze wiele śladów tych wierzeń [zob. SSiSL]. Wspomniane duchy miały moc m.in. wpływania na wiatr, tym samym na pogodę. Będzie jeszcze o tym mowa.

3. Powietrze jako substancja

3.1. Podstawowym znaczeniem leksemu powietrze przez stulecia jest to, co dziś określamy jako 'mieszaninę gazów otaczającą ziemię'. Współczesna definicja nie odpowiada oczywiście dawniejszym wyobrażeniom, o których jednak nie wiemy zbyt wiele. Zapewne lepiej byłoby przyjąć ogólną definicję zaproponowaną w SSiSL, w której czytamy, że powietrze

jest tym, czym oddychamy i co wypełnia najbliższą przestrzeń między ludźmi a rzeczami, a szerzej niebem [s. 287].

Ta niedookreśloność materialna jest w opisie historycznym szczególnie ważna i co więcej, zapewne bliska przeciętnej dawnej wrażliwości.

5 Ich wyrazista etymologia wskazuje na bezpośrednie powiąania $z$ powietrzem. Trzeba jednak przyznać, że nie mamy pewności co do prasłowiańskich źródeł niektórych $z$ nich. Pełny ich opis znajduje się we wspomnianej pracy Zuzanny Krótki [2016]. 
Trudno o wypowiedzi, które pokazywałyby potoczne myślenie, zwłaszcza we wcześniejszych wiekach, pojawiaja się dość ogólne stwierdzenia typu:

Powietrza choć nie widzisz /ale przedsię czuiesz Rej Wiz 113v [SXVI].

Oczywiście, pewne cechy powietrza, takie jak ulotność, przeźroczystość, od zawsze były podkreślane choćby w metaforach. Sporo takich odniesień odnajdziemy i w historii, i we współczesności, por. XVI-wieczne na powietrzu łowić (to jest tam szukać gdzie nie masz nic [Mącz. 301a, SXVI], na powietrzu pokazywać, na powietrzu zamki budować, czy obecne traktować kogoś jak powietrze. Dodać do tego można byłoby charakterystyczna semantykę niektórych derywatów, np. powietrzność w znaczeniu 'sterylność, przejrzystość, zwiewność, ulotność'. Powyższy przykład pochodzi z XIX wieku (Postaci Mickiewicza, choćby fantastyczne, sa nawet $w$ swej pieszczotliwości i powietrzności stosunkowe krzepkie i kraża bardzo blizko ziemi $\mathrm{Chm}$ [Swar]).

Powietrze w tym ogladzie jest czymś, co nas otacza, zmienia się, stając się raz jasne lub mgliste, a raz wichrowate, nawalne, nie dziwia zatem znaczenia 'stan pogody, "klimat".

Ewolucję omawianego pojęcia możemy uważniej prześledzić w czasach nowożytnych w tekstach o charakterze naukowym, które dostarczają nam już wielu explicite wyrażonych sądów. Wspominam o tym, gdyż możemy założyć, że sady te miały wpływ na powszechny sposób myślenia. Pouczająca jest lektura książki Lublin podług ustaw medyki uwazany $w$ iedney dyssertacyi Michała Bergonzoniego, obcokrajowca przybyłego do Polski w 1775 roku: ${ }^{6}$

Powietrze ieft ciało płynne leksze w porownaniu do innych ciał iednakże swoię ciężkość maiące, przezroczyste bez zapachu bez smaku sprężyste prędkie do rozrzedzenia się i do zgęszczenia które pod żadne $z$ naszych zmysłow procz dotykania nie podpada; takie powietrze bardzo czyste mimo wszystkich staranności Fizykow bydź otrzymane nie może to zaś które nas otacza i które całą zastępuie naszą atmosfere iest zmieszane z maleńkiemi cząsteczkami ciał rożnego gatunku [1782, rozdz. VIII].

A oto jeszcze jedna ilustracja, tym razem $z$ dziewiętnastowiecznego podręcznika:

Cała ziemię otacza powietrze. Jest to ciało sprężyste, płynne i bardzo lekkie, przenikające wszystkie ciała. Chociaż powietrza nie widzimy jednak je czujemy, gdy wiatr powiéwa albo gdy machniemy książką [Józefczyk 1869, 13].

Wszystkie te przykłady dokumentuja, jak zmienia się w historii postrzeganie istoty powietrza i uświadamiaja, że diachroniczny opis definicyjny powinien to uwzględniać.

${ }^{6}$ Informacje o tym lekarzu, uczonym, można odnaleźć w: Sejda 1971. 
3.2. Powróćmy jeszcze raz do tekstu Stanisławy Niebrzegowskiej-Bartmińskiej i Jerzego Bartmińskiego. Badacze ci zwracaja uwagę, że powietrze jest par excellence żywiołem ze względu na silny związek $\mathrm{z}$ ruchem, związek, który widzimy już w etymologii słowa [2017, 22]. I rzeczywiście, współcześnie mówimy o powietrzu, że drży, faluje, wibruje, przepływa itd. Warto jednak zaznaczyć, że nie łączymy go $z$ ruchem tak wyraziście jak w historii.

Ów związek poświadczaja przede wszystkim wspólne, zgodne $z$ geneza, zakresy użycia leksemów powietrze i wiatr, rejestrowane w staropolszczyźnie i w dobie średniopolskiej, wszak wiatr jest zruszenie powietrza (...) Boh. Diab. 172 [SXVI] i podobnie Knapiusz, a za nim S.B. Linde pisza, że powietrze to 'jeden $z$ żywiołów, wiatr, którym oddychamy, po którem ptactwo lata' [SL].

Obecnie, $z$ punktu widzenia sensu językowego, niemożliwe są zdania typu:

I ludzie i żywioły i wszystko stworzenie było mu przeciwno / bo powietrze wielkie dom jego (...) przewróciło... JanKoszŻywF2 [SXVI].

Przeto jąwszy go za nogi i za rece / wrzucili go w morze /gdzie go natychmiast wieloryb połknął / i ucichło im powietrze. BielKron 92 [SXVI],

tak jak nie do końca zrozumiałe jest przeklęcie: Bodaj nas powietrze porwało nami miotało KlonFlis H3v [SXVI]. Ale też odwrotnie, leksem wiatr mógł oznaczać 'powietrze':

Ten ps $<$ alm $>$ powyada, yze Xpus stworzyl zywyoly, to yest zyemye, wyatr, ogye $<$ ń $>$, wodę Put 73 arg [Sstp].

Wiatr tylko siekł, i machał po wietrze bez skutku, bo mu przeciwnik zaraz ubiegł na powietrze PKoch [SL].

Zimny i ciepły wiatr (dech) $z$ jednych ust wypuszczać L [Swar].

Trudno w analizach, zwłaszcza historycznych, oddzielać te dwa zjawiska, tym bardziej iż historia wyraźnie je łączy w jedną całość. Kilka słów należałoby zatem poświęcić wiatrowi.

3.3. W nazwach określajacych wiatr, czyli owo „poruszenie powietrza”, zachowane zostały wyraźnie charakterystyczne cechy dawnego wyobrażenia o tym żywiole, o których częściowo była mowa. Wiatr w historii języka ma sporo odpowiedników leksykalnych rodzimych, wyznaczających różne jego rodzaje, oprócz powietrza są to np.: dma, dmuch, wicher, wichura, nawałność, powicher przewał [por. SXVI]. Dopiero później dochodzą do tego również pochodzenia obcego zefirus, huragan itd. Nazwy rodzime zwiazane sa zwykle $z$ prostymi określeniami ruchu, ale nie tylko. Warto zwrócić uwagę na rzeczownik $d u c h \mathrm{w}$ takiej funkcji, leksem o bardziej skomplikowanej semantyce i złożonych powiązaniach pojęciowych. Podkreślmy za autorami SXVI, iż występuje on, co znaczące, głównie w tekstach thumaczeniowych: 
Párá / y ogiéń gorący / Grad / y śniég zniebá płynący Y prędkié duchy wichrowé [spiritus procelarum Vulg Ps 148/8] Ná páńskié słowá gotowé. KochPs 214 [SXVI].7

Ciekawsze sa jednak nazwy typu diabet, złe, diabelski młyn zachowane w gwarach, które bezpośrednio pokazuja stosunek człowieka do zjawisk przyrody. Utrwalone w nich zostały dawne wierzenia, przekonanie, iż niszczycielskie własności wiatru wywodzą się często $z$ demonicznych działań. Jak podkreśla Władysław Kupiszewski, opisując gwary:

(...) Powszechnie sądzi się, że (wiatr) zjawisko to wywołane jest siłami nieczystymi, najczęściej przez diabła lub czarownice [1969, 56; zob. też SSiSL].

Co więcej, nazwy ludowe zachowuja ślady dawnych obrzędów, związanych $z$ walka $z$ gwałtownym żywiołem. Oto choćby jeden przykład: świńskie gówno jako określenie wiru powietrznego. Wyjaśnienie sensu odnajdziemy znów u wymienionego uczonego:

Pierwotnie niektórzy Słowianie (..) odstraszali złego ducha lecacego w wirze powietrznym okrzykiem: świńskie gówno! $Z$ czasem zaniechano tej praktyki, ale okrzyk pozostał jako nazwa omawianego zjawiska [1969, 57-8].

Wielość i ekspresja nazw silnego wiatru nie zaskakuje, jest żywiołem budzącym respekt i strach. Rzadziej, choć i o tym warto wspomnieć, odnajdziemy w języku ślady traktowania wiatru jako zjawiska pożądanego, por. np. powietrze wdzięczne oznaczające w słowniku Calepina 'lekki przyjemny wiatr' [SXVI] czy metaforyczne znaczenie przymiotnika powiewny 'pomyślny, pocieszający, szczęśliwy, przyjemny, pożądany': Powiewniejsze otrzymat nowiny [Swar].

3.4. Powietrze jako siła, żywioł często o charakterze negatywnym, zwiazane jest wbrew pozorom nie tylko $z$ sensu stricto fizycznym niszczeniem. Było coś, co przerażało ludzi znacznie bardziej: morowe powietrze.

Powietrze dla człowieka ma podwójny charakter, $z$ jednej strony jest źródłem życia. Przypomnijmy kilka cytatów: powietrze chłodzi, żywi, otrzeźwia człowieka Rej. Ap 78 [SL], powietrze jest stroż żywota BielZyw 136 [SXVI] i współczesnych zwrotów: potrzebować czegoś jak powietrza czy tak znany i często powtarzany: widać, można żyć bez powietrza [M. Jasnorzewska]. Warto też wspomnieć o średniowiecznej koncepcji człowieka i wiazaniu jego istnienia $z$ czterema żywiołami. $Z$ drugiej strony jednak powietrze może przynieść śmierć, nieszczęścia, zazwyczaj wówczas traktowane jako kara boska. O tej jego własności wspomina się $\mathrm{w}$ tekstach średniopolskich niezwykle często, co jest naturalne, biorac pod uwagę, jak wielkim zagrożeniem były epidemie, bo o nich jest mowa. Określane różnie jako złe, nieczyste, zepsute, grube, zarażone, jadowite, zgniłe, roznoszone przez wiatr, powszechnie było uznawane, i to nie tylko

7 Takie samo znaczenie ma duch w języku staroczeskim. 
w Polsce, za podstawowa przyczynę szerzacej się zarazy (dżumy, duru plamistego itd.), a także wielu chorób, takich jak np. paraliż $\dot{z}^{8}$ [por. Burchardt, Burchardt 2008]. Jak zaznacza F. Giedroyć, pisząc o XVIII wieku:

Większość ówczesnych medyków wyobrażała sobie istotę „zarazy” w postaci jakieś nieuchwytnej, „mgły gestej”, „zaduchu” (...), ,jadowitej pary” (...), „waporu” [Giedroyć $1899,69]$.

Wyrażenie morowe powietrze obok zaraza (morowa, powietrzna), mór itd. notowane jest już w Sstp. Rzeczownik powietrze tak często występował w wymienionych kontekstach, że sam przybrał wtórne znacznie 'zaraza', które rejestrują wszystkie podstawowe słowniki.

Powietrze morowe można byłoby, jak sądzę, rozpatrywać w kategorii żywiołu: raziło, zarażało, porażało, ruszało, por. np.:

Bodajżę was powietrze ruszyło! A długoż obudwu będziecie kpić> MorszHSumBar_I 1650 [Korba].

Bodayby powietrze zaraziło tego psa pogańskiego. Mon. 68, 516 [SL].

Gdy się rozgniewał, ruszyło go powietrze, i w kilka dni umarł. Biel. 276 [SL].

Widzimy w tych, którzy są powietrzem abo paraliżem zarażeni, że więc rękę i nogę im odeymuje Sak. pr. 83 [SL].

Zwykle nie jest traktowane jako bierny nośnik zarazy. Jego dynamizm widoczny jest też w innych kontekstach:

Byłem na Ukrainie w dobrach swoich, kędy nie wiele zmieszkawszy do Litwy musiałem regres uczynić dla powietrza wkoło grasujacego. ZawiszaPam 32 [Korba].

Powietrze po niektórych miejscach koło Krakowa zjawiło się i rozszerzało ZawiszaPam 253 [Korba].

Anno 1708 wielkie powietrze od Krakowa do Warszawy przyszło ZawiszaPam 363 [Korba].

A oto przykład $z$ synonimicznym $\mathrm{w}$ tym wypadku leksemem wiatr:

Nie życzyłam, żeby kiedy na cię zły wiatr wionął Tward. Pas, 13 [SL].

W języku zatem zachowane jest przynajmniej częściowo pierwotne odczuwanie sprawczej roli powietrza w rozprzestrzenianiu się epidemii, choć dosyć wcześnie, co zwykle się podkreśla, zaczęto łączyć szerzenie się zarazy z zachowaniem się człowieka [por. SSiSL]. W tekstach średniopolskich odnajdziemy szereg szczegółowych i dramatycznych opisów walki o życie, także związanych z koniecznością izolacji chorych [por. np. Jarczykowa 2015]. We współczesnej frazeologii, o czym wspomina Agnieszka Piela [2020], zachowało się trochę jeszcze świadectw tamtych

8 Warto w tym wypadku pamiętać też o biblijnych korzeniach tych przekonań. 
czasów, por. bać się kogoś jak morowego powietrza, omijać kogoś jak zapowietrzonego.

Dodajmy na zakończenie, że swoisty lęk przed powietrzem istnieje również współcześnie, ma jednak zupełnie inny wymiar, związany jest bowiem ze smogiem, zanieczyszczeniami, kojarzonymi głównie $z$ działalnością ludzka, dający zatem poczucie, że można nad nim zapanować. Nowe słownictwo, inne określniki pojawiające się przy rzeczowniku powietrze (np. zanieczyszczenie, zanieczyszczony, smog) doskonale pokazują zachodzace przeobrażenia.

W niniejszym artykule zaproponowałam jedynie szkicowa analize (i to przede wszystkim zwracajacc uwagę na historię) tego ciekawego pojęcia, zmiennego i pełnego ambiwalencji. Pojęcie to ewoluowało wraz ze sposobem myślenia o świecie, wraz $z$ narastającym poczuciem pewności człowieka wobec żywiołów, tym samym słabł też i ludzki lęk.

Pełny opis powietrza i jednocześnie jego odpowiednika leksykalnego wymagałby $z$ pewnością bardzo dokładnych historycznych prac porównawczych. Większość zmian w jego pojmowaniu wiąże się bowiem $z$ ogólnym kierunkiem przeobrażeń zachodzących w kulturze europejskiej. Zaledwie na niewielka część zwróciłam uwagę. Dopiero takie tło kulturowo-językowe umożliwiłoby w pełni dostrzeżenie specyfiki polskiej.

\section{Bibliografia}

J. Bartmiński, S. Niebrzegowska-Bartmińska, 2017, Czym są żywioły w polskiej tradycji ludowej? [w:] Żywioły w poznaniu, t. 1: Metodologie badañ z perspektywy językoznawczej i literaturoznawczej, red. E. Pawlikowska-Asendrych, Częstochowa, s. 11-36.

M. Bergonzoni, 1782, Lublin podług ustaw medyki uwazany $w$ iedney dyssertacyi, Lublin.

J. Burchardt, D. Burchardt, 2008, Morowe powietrze - krótki szkic do historii zarazy na ziemiach polskich w pierwszej połowie XVIII wieku, „Nowiny Lekarskie" 77, 4, s. 334-338.

F. Giedroyć, 1899, Mór w Polsce w wiekach ubiegłych - zarys historyczny, Warszawa.

A. Guriewicz, 1987, Problemy średniowiecznej kultury ludowej, tłum. Z. Dobrzyniecki, Warszawa.

N. Gryzińska, 2011, Sacrum i profanum - żywioly $w$ średniowieczu i dziś [w]: M. Kania, D. Kobiałka (red.), Biografie żywiołów. Kulturowy wymiar świata, Poznań, s. 45-61.

M. Jankiewicz-Brzostowska, 2007, Wybrane średniowieczne wyobrażenia zwiazane z żywiołem powietrza [w:] M. Mazurczak, M. Żak (red.), Obraz i żywioky, Lublin, s. 305-319.

M. Jarczykowa, 2015, „Powietrzna zaraza” w Wielkim Księstwie Litewskim $w$ ujeciu Walentego Bartoszewskiego i Piotra Kochlewskiego [w:] M. Jarczykowa, B. Mazurkowa, S. Dabrowski (red.), Świat bliski i świat daleki w staropolskich przestrzeniach, Katowice, s. 153-172. 
A. Józefczyk, 1869, Ksiażka do czytania dla wyższych szkół elementarnych nakładem J. Milikowskiego, Lwów.

Z. Krótki, 2016, Nazwy demonów powietrznych w historii języka polskiego, „Białostockie Archiwum Językowe" 16, s. 159-172.

W. Kupiszewski, 1969, Słownictwo meteorologiczne w gwarach i historii jezyka polskiego, Wrocław-Warszawa-Kraków.

K. Libelt, 1875, Filozofia i krytyka, t. 5: Estetyka czyli Umnictwo piękne, cz. 1: Piękno natury, Poznań.

S. Niebrzegowska-Bartmińska, Język jak powietrze - ożywcze czy morowe?; http:/ /www.etykaslowa.edu.pl/wp-content/uploads /2016/03/ J\%C4\%99zyk-jak-powietrze-0\%C5\%BCywcze-czy-morowe.pdf

E. Pawlikowska-Asendrych, 2012, Niemieckie pojęcie „luft” w konceptualizacji procesów emocjonalnych i poznawczych [w:] H. Kaczmarek (red.), Żywioły $w$ poznaniu, t. 2: Konceptualizacja żywiołów. Wieloaspektowość badań- różnorodność rozwiazañ, Częstochowa, s. 163-180.

A Piela, 2020, W cieniu koronawirusa... historycznie o zarazie i zarazkach, „Poradnik Językowy" z. 6, s. 97-105.

P. Skarga, 1579, Zywotow Swiętych stárego y nowego zakonu z pifmá świętego y $z$ poważnych pifarzow y Doktorow kosćielnych wybranych; http://spxvi. edu.pl/korpus/teksty/SkarZyw/

B. Sejda, 1971, Dwaj cudzoziemcy prekursorami medycyny społecznej $w$ Polsce: Michelangelo Bergonzoni $i$ Leopold Lafontaine, „Kwartalnik Historii Nauki i Techniki" 16/3, s. 517-534.

S. Wilk, 2007, Słowo wsteppne [w:] M. Mazurczak, M. Żak (red.), Obraz i żywioły, Lublin, s. 9-10.

J. Wujek (tłum.), 1599, Biblia. To jest Ksiegi Starego y Nowego Testamentu, według łacińskiego przekłádu stárègo, w kościele powszechnym przyiętègo, ná polski ięzyk $z$ nowu $z$ pilnościa przełożonè (...), Kraków.

https://www.wbc.poznan.pl/dlibra/publication/5389/edition/9662/content

\section{Słowniki}

DWDS - Digitales Wörtebuch der deutschen Sprache mit etymologischem Wörtbuch; www.dwds.de

Korba - W. Gruszczyński (kier.), Elektroniczny korpus tekstów polskich z XVII i XVIII w. (do 1772 r.); https:/ / korba.edu.pl

SDor - W. Doroszewski (red.), 1958-1969, Słownik języka polskiego, t. 1-11, Warszawa.

SS - Igor Němec, J. Pečírkova (red.), 1968-2008, Staročeský slouník, t. 1-26, Praha; https://vokabular.ujc.cas.cz/hledani.aspx

SSiSL - G. Bacczkowska, J. Szadura (oprac.), Słownik stereotypów i symboli ludowych, t. 1: Kosmos, cz. 3-4: Meteorologia: świat, światło, metale, Lublin; Powietrze, s. 287-298.

SL - S.B. Linde, 1994-1995, Słownik języka polskiego, t. 1-6, Warszawa (reprint). Sstp - S. Urbańczyk (red.), 1953-2002, Słownik staropolski, Wrocław-Warszawa-Kraków.

SXVI - M.R. Mayenowa, F. Pepłowski (red.), 1967-, Słownik polszczyzny XVI wieku, t. 1-37, Wrocław-Warszawa; http://spxvi.edu.pl/

SWar - J. Karłowicz, A. Kryński, W. Niedźwiedzki (red.), 1900-1927, Słownik języka polskiego, t. 1-8, Warszawa. 
B. Sieradzka-Baziur (kier.), Słownik pojęciowy języka staropolskiego; https:// spjs.ijp.pan.pl/

\section{Between fear and fascination.}

The notion of POWIETRZE (AIR) in the history of the Polish language

Summary

This paper, which proposes a historical overview, is dedicated to the notion of < powietrze > (air) and its lexical equivalent in the Polish language. This notion has undergone numerous changes over time; it has formed through direct human experience on the one hand and through the Christian and Slavic traditions as well as scientific knowledge overlapping on the other hand. This notion has always been important to the human being, it has been commonly referred to in metaphors and similes.

In the historical analysis, two basic senses of powietrze (air) were taken into consideration: 'place' and 'substance'. In both cases, there has always been a clearly ambivalent attitude to the human being, who sees threats on the one hand and feels that air guarantees life on the other hand.

Keywords: notion - semantic change - history of Polish - historical lexis

Trans. Monika Czarnecka 